\title{
Human resource practices as predictors of engineering staff's organisational commitment
}

\begin{tabular}{|c|c|}
\hline \multicolumn{2}{|c|}{$\begin{array}{l}\text { Authors: } \\
\text { Melinde Coetzee }^{1} \\
\text { Jeremy Mitonga-Monga }^{1} \\
\text { Benita Swart }^{1}\end{array}$} \\
\hline \multicolumn{2}{|c|}{$\begin{array}{l}\text { Affiliations: } \\
{ }^{1} \text { Department of Industrial } \\
\text { and Organisational } \\
\text { Psychology, University of } \\
\text { South Africa, South Africa }\end{array}$} \\
\hline \multicolumn{2}{|c|}{$\begin{array}{l}\text { Correspondence to: } \\
\text { Melinde Coetzee }\end{array}$} \\
\hline \multicolumn{2}{|c|}{$\begin{array}{l}\text { Email: } \\
\text { coetzm1@unisa.ac.za }\end{array}$} \\
\hline \multicolumn{2}{|c|}{$\begin{array}{l}\text { Postal address: } \\
\text { PO Box 392, Pretoria 0003, } \\
\text { South Africa }\end{array}$} \\
\hline \multirow{2}{*}{\multicolumn{2}{|c|}{$\begin{array}{l}\text { Dates: } \\
\text { Received: } 25 \text { Oct. } 2013 \\
\text { Accepted: } 13 \text { June } 2014 \\
\text { Published: } 28 \text { Oct. } 2014 \\
\text { How to cite this article: } \\
\text { Coetzee, M., Mitonga- } \\
\text { Monga, J., \& Swart, B. (2014). } \\
\text { Human resource practices } \\
\text { as predictors of engineering } \\
\text { staff's organisational } \\
\text { commitment. SA Journal } \\
\text { of Human Resource } \\
\text { Management/SA Tydskrif vir } \\
\text { Menslikehulpbronbestuur, } \\
\text { 12(1), Art. \#604, } 9 \text { pages. } \\
\text { http://dx.doi.org/10.4102/ } \\
\text { sajhrm.v12i1.604 }\end{array}$}} \\
\hline & \\
\hline \multicolumn{2}{|c|}{$\begin{array}{l}\text { Copyright: } \\
\text { (C) 2014. The Authors. } \\
\text { Licensee: AOSIS } \\
\text { OpenJournals. This work } \\
\text { is licensed under the } \\
\text { Creative Commons } \\
\text { Attribution License. }\end{array}$} \\
\hline \multicolumn{2}{|c|}{ Read online: } \\
\hline arisg & $\begin{array}{l}\text { Scan this QR } \\
\text { code with your } \\
\text { smart phone or } \\
\text { mobile device } \\
\text { to read online. }\end{array}$ \\
\hline
\end{tabular}

Orientation: Human resource practices are an important means of retaining professionally qualified employees and improving and increasing their future level of organisational performance in today's turbulent and perpetually competitive world of business.

Research purpose: This study examined whether human resource practices (as a core aspect of organisational culture) positively predict organisational commitment.

Motivation for the study: In South Africa, high voluntary turnover and skills shortages of professionally qualified people such as engineers are a major obstacle to economic growth and job creation.

Research design, approach and method: A cross-sectional survey and quantitative design were used with a non-probability purposive sample of 284 early career professionally qualified engineers from a South African engineering organisation. Correlational statistical techniques were employed to achieve the research objective.

Main findings: Job satisfaction, training and development and rewards and remuneration positively predicted affective commitment. Leadership, rewards and remuneration and training and development also positively predicted normative commitment. Human resources policies and procedures positively predicted continuance commitment.

Practical/managerial implications: Managers and human resource practitioners need to take a proactive approach in facilitating an organisational culture that reflects the practices embodied by the variables measured in this study in order to increase organisational commitment.

Contribution: The findings add new knowledge that may be used to help managers and human resource practitioners understand how these human resource practices may guide retention strategies in the engineering environment.

\section{Introduction}

Human resource (HR) practices have become an increasingly important means for an improved business approach in order for an organisation to survive, remain competitive, sustain its business functions and grow in an ever-changing and competitive environment (Papulova \& Papulova, 2006). HR practices have therefore become an essential aspect of organisational culture in retaining professionally qualified employees such as engineers (Aggarwal \& D'Souza, 2012; Chang, Wang \& Huang, 2013; Deloitte \& Touche, 2009). The May 2014 draft of the South African National Scarce Skills List indicated engineering skills as on one of the top five scarce critical skills for economic growth (Department of Higher Education and Training [DHET], 2014). The high voluntary turnover and skills shortages (Wöcke \& Heymann, 2012) of professionally qualified people such as engineers seem to be a major obstacle to economic growth and job creation (Construction Education and Training Authority [CETA], 2007; Döckel, 2003; Kraak, 2008; Rasool \& Botha, 2011). The skills shortages further seem to limit South African businesses' level of global participation (Rasool \& Botha, 2011). To deal with these challenges, organisations are continuously striving to improve their culture and implement HR practices that will enable them to survive, retain talented employees, remain competitive, sustain their business functions and grow in a turbulent business environment (Arachchige \& Robertson, 2011; Coetzee \& Veldsman, 2013).

\section{Background}

In the present study, HR practices are studied as an aspect of organisational culture. Deloitte and Touche's (2009) approach to measuring organisational culture focuses on the HR practices that represent the top world-class companies. Rashid, Sambasivan and Johari (2002) posit that the human resource practices associated with high-performing organisational cultures have attracted academia and practitioner attention over the past two decades because of their effects and 
potential impact on organisational success and staff retention in the contemporary and future world of work. Previous studies have indicated that the underlying values, beliefs and principles embedded in an organisation's culture serve as a valuable foundation for an organisation's management system and are exemplified and reinforced by the company's HR practices and behaviours (Abu-Jarad, Yusof \& Nikbin, 2010; Eskildsen \& Dahlgaard, 2000; Martins \& Martins, 2002). Organisational culture, including the HR practices that represent the culture, is regarded as a strong strategic lever in creating an engaged and committed workforce (Martins \& Coetzee, 2007).

Amah (2012) draws attention to the fact that the hypothesis that strong cultures enhance organisational performance is based on the intuitively powerful idea that organisations benefit from highly committed, motivated employees dedicated to common goals. For instance, organisational commitment is perceived as a key determinant of employee turnover due to its supposed sensitivity to the elements surrounding the work environment (Chang et al., 2013; Döckel, Basson \& Coetzee, 2006; Meyer \& Allen, 1991). The work environment is regarded as a combination of the psychological environment, HR practices and corporate culture that enable employees to perform their jobs with appropriate support or workplace flexibility, ongoing training opportunities (including teaching job, social and leadership skills) and clear career path and advancement opportunities (Amah, 2012; Döckel, 2003).

Previous studies have shown that organisational culture and HR practices (for example, leadership behaviour, performance management, training and development, compensation and communication) influence employee satisfaction, turnover intentions and organisational commitment (Chang et al., 2013; Döckel, 2003; Martins \& Coetzee, 2007; Swart, 2009). Research further indicates that organisational commitment can lead to favourable organisational outcomes, including organisational effectiveness, improved performance and reduced staff turnover (Meyer \& Allen, 1997; Saif, Nawaz, Jan \& Khan, 2012).

\section{Research objective}

The present study explored whether human resource practices act as predictors of organisational commitment in the engineering profession.

\section{Potential value-add}

Although various studies exist internationally that highlight the significance of organisational culture and the concomitant HR practices that support high-performing firms, there seems to be a paucity of research concerning how HR practices relate to employees' organisational commitment in the South African engineering context. In view of the current skills shortages and concerns about attracting and retaining professionally qualified engineers (CETA, 2007; DHET, 2014; Swart, 2009), the present study seems timely and important.

\section{Literature review Organisational commitment}

Organisational commitment refers to the relative strength of an individual's identification with and involvement in a particular organisation (Ezirim, Nwibere \& Emecheta, 2012), the extent to which employees are willing to work on its behalf and the likelihood that they will maintain membership of the organisation (Dey, 2012). Reade and Lee (2012) and Kuo (2013) found organisational commitment to be typically associated with characteristics, jobs and behaviours of staff, as well as the socio-cultural environment of an organisation. Meyer, Stanley and Parfyonova (2012) regard organisational commitment as a psychological state or mindset that binds an employee to the organisation. Organisational commitment comprises a strong emotional component and includes general interests, principles, values and goals (Tsai \& Cheng, 2011).

In the context of the present study, the notion of organisational commitment is based on Meyer and Allen's (1997) three-component model of organisational commitment: (1) the psychological state that reveals the level of an individual's commitment and emotional attachment towards an organisation (affective commitment), (2) the pre-existing conditions leading to the development of that commitment level (continuance commitment) and (3) the behaviours that are expected to result from this commitment (normative commitment).

Affective commitment refers to the employee's emotional attachment to, identification with and involvement in the organisation (based on positive feelings or attitudes towards the organisation). In this case, employees strongly identify with the goals of the organisation and want to remain a part of the organisation (Ezirim et al., 2012). Continuance commitment refers to commitment based on the cost that the employee associates with leaving the organisation (due to the high cost of leaving). In this case, the employee remains with an organisation because of a perceived loss of sunken costs (Ezirim et al., 2012). In terms of normative commitment, the employee remains with an organisation because of a sense of obligation. For instance, individuals may feel that they ought to remain with an organisation because they think that it is morally right to continue to participate in the same organisation. An organisation may also have invested more resources in training an employee, who then feels obliged to stay with the organisation to repay the debt (Ezirim et al., 2012).

In terms of social exchange theories, the strong link between individuals' commitment to an organisation or occupation implies that employees are more committed after they have weighed the pros and cons following resignation (Kuo, 2013; Rothrauff, Abraham, Bride \& Roman, 2011). Kuo (2013) therefore argues that organisational commitment is an effective and highly influential mechanism for connecting employees and the organisation. It also provides cohesion and motivates employees to devote long-term effort to 
addressing external influences and meeting customer demands (Kuo, 2013). Bang, Ross and Reio (2013) support the principle of social exchange theory and indicate that when the values of employees meet the values of the organisation, the strength of employees' commitment will become greater, to the extent that they could demonstrate blind commitment, which will lead them to sometimes accept the status quo, resulting in the organisation losing its ability to be innovative and adapt to change.

Ezirim et al. (2012) found that organisational commitment is positively related to a variety of desirable work outcomes, including employee job satisfaction, motivation and performance, and negatively correlated to absenteeism and turnover. Van Dyk and Coetzee (2012) found a strong positive relationship between organisational commitment and HR-related retention practices, which appear to bind individuals to their organisation in the medical and information technology services environments.

\section{Human resource practices}

HR practices have assumed considerable importance in the 21stcentury because of their impact on employee performance, job satisfaction, commitment and retention (Momeni, Marjani \& Saadat, 2012). In general, it can be assumed that employees who perceive that their organisation invests in sound HR practices that address their needs will be psychologically and emotionally committed to the organisation (Swart, 2009). HR practices refer to the management processes and systems that are widely recognised as improving an organisation's performance and efficiency (Brundage \& Koziel, 2010; Döckel, 2003). Scholars have studied this topic by testing numerous types of performance improvement or performance enablers over the years with the aim of identifying and establishing those systems and practices that can help organisations to achieve their envisaged state of excellence (Brundage \& Koziel, 2010; Döckel, 2003).

The global consulting company Deloitte and Touche (2009) identified the following 13 core HR practices that are essential to a high-performing culture. These practices are seen to affect a company's performance and therefore deemed to be important for a creating a strong performance-oriented organisational culture:

- Leadership relates to the extent to which employees perceive their senior leaders' level of communication, openness and honesty, as well as the way in which leaders are seen to model the organisational values and inspire employees. Research suggests that leaders who treat people in the right ways have a high level of moral development and act with integrity positively influence employees' affective commitment (Detert \& Treviño, 2010).

- Management style relates to the extent to which employees perceive the accessibility of their manager or supervisor, as well as whether or not the manager provides them with the necessary resources to accomplish their jobs, consults with employees regarding important decisions, sets realistic performance goals and acknowledges them as individuals. According to Zeffane (1994), management style can significantly influence the degree of worker commitment to organisational values and goals.

- Communication refers to the effectiveness of the internal organisational communication channels, the frequency and quality of communication, communication between management and employees and between departments and the extent to which employees are consulted when decisions are being taken that will impact upon them. Ghina (2012) posits that affective commitment might be enhanced under conditions of high organisational communication and involvement of workers in the decision-making process. As individuals are consulted and involved in matters that concern them, strong feelings of loyalty to the organisation may develop.

- Values and culture refer to employees' perceptions regarding their company's vision, mission and values, as well as their experience of the organisational culture insofar as it is employee-centred and promotes good working relationships, trust and transparency. It appears to be that congruence between personal and organisation values and culture is highly motivating and may increase organisational commitment (Coetzee \& Veldsman, 2013; Khandelwal \& Mohendra, 2010). Employees' personal values and culture have been found to be related to affective commitment (Rostami, Veismoradi \& Akbari, 2012).

- Innovation refers to whether or not the organisation continuously comes up with new ideas and innovations in every area, thereby growing its revenue through innovation. Pandey and De (2013) indicate that innovation is the only way for companies to obtain a competition position. It is also the principal factor to trigger business growth. Innovation results in companies creating new products, systems and service items to meet the demands of customers. Innovation practices were found to be related to affective commitment (Pandey \& De, 2013; Swart, 2009).

- Job satisfaction refers to the extent to which employees have clear work objectives, whether or not they have access to the necessary tools and resources to do their jobs effectively and are afforded the opportunity to fully utilise their talents and skills in their jobs. According to Shah, Jatoi and Memon (2012), employees with clear objectives and who are provided with the necessary tools and resources to carry out their jobs can develop a positive attitude towards the job and organisation. Employees' job satisfaction has been found to be related to affective and continuance commitment (Shah et al., 2012).

- HR policies and procedures refer the extent to which appropriate HR policies and procedures are in place and are easily accessible to and understood by employees. Research by Juhdi, Pa'Wan, Milah, Hansaram and Othman (2012) shows that properly implemented and managed $\mathrm{HR}$ policies and procedures increase 
organisational commitment and decrease intention to resign amongst employees.

- Performance management refers to the perceived fairness and consistency of implementation as experienced by employees. According to Lin, Lin and Lin (2012), performance management enhances employees' organisational commitment. Psychological commitment is higher amongst highly skilled engineering workers who believe that their company is fair and consistent in the implementation of performance management (Decremer, Smolders, Vanderstraeten \& Christiaens, 2012).

- Recognition refers to the extent to which employees perceive recognition (e.g. promotions, verbal recognition, awards) to be effective and fairly implemented within the organisation. According to Zaitouni, Sawalha and Sharif (2011), monetary compensation is important, but not sufficient to retain employees. Recognition in the form of non-monetary elements (e.g. verbal recognition and positive feedback) is also important. Paré and Tremblay (2007) indicate that recognition from managers and peers has been found to be related to affective and continuance commitment.

- Rewards and remuneration refers to the extent to which employees perceive their remuneration to be market-related and appropriate to their job roles and responsibilities. This practice also explores the nature of benefits and bonus and incentive schemes offered by the organisation. It appears that fair rewards affect organisational commitment. Previous research has shown that rewards for quality efforts appear to positively influence employee morale and satisfaction (Martins \& Coetzee, 2007). Research by Zaitouni et al. (2011) suggests that employees who are provided with benefits, such as increased salary, bonuses and promotion, develop strong feelings of loyalty to the organisation. Perceptions of fair rewards and justice lead to higher levels of satisfaction and long-term commitment to the organisation.

- Training and development refers to the nature of training and development within the organisation in terms of its availability, applicability to employees' current and future job roles and the range of training opportunities available (Deloitte \& Touche, 2009). Training is used to enhance specific skills and correct performance issues to empower employees with needed skills for current and future job requirements. Döckel et al. (2006) indicate that employees seem to develop a sense of obligation (normative commitment) and stay longer in an organisation that promotes career opportunity through learning and the ability to apply newly learned competencies.

- Diversity and transformation refers to the extent to which diversity management is applied within the organisation, with a particular focus on the equitable treatment of employees from different ethnic, gender and age groups. According to Jonsen, Tatli, Ozbilgin and Bell (2013), affective and normative commitment may be enhanced under conditions of good equitable treatment and nondiscrimination. Jonsen et al. (2013) indicate that an engineering work environment that provides equitable fair treatment has the reputation of retaining talented workers.

- Change management refers to how the change management process is dealt with in the organisation and how employees are managed throughout the change process in terms of adequate communication, involvement and support. Visagie and Steyn (2011) indicate that employees' commitment to the organisation is critical when an organisation engages in change initiatives. Committed employees can therefore provide many benefits, for example by putting in extra effort to ensure that change succeeds, serving as public relations representatives during the change and going above and beyond the norm to assist the organisation to function effectively (Visagie \& Steyn, 2011).

Juhdi et al. (2012) describe HR practices as the methods that organisations use to mould employee behaviour, perception and attitudes. Organisational culture surveys of employees' perceptions of the $13 \mathrm{HR}$ practices identified by Deloitte and Touche (2009) enable organisations to observe which practices foster employee commitment, satisfaction and productivity and which hinder employee satisfaction and productivity. This valuable information can then be used to improve current organisational HR practices, thereby increasing staff satisfaction, commitment and productivity and reducing staff turnover.

Drawing on the research literature and previous empirical findings, we hypothesised that HR practices positively and significantly predict individuals' affective, continuance and normative commitment.

\section{Research design Research approach}

A cross-sectional, quantitative survey design approach was used to achieve the objectives of the study.

\section{Method Participants}

A non-probability purposive sample of a total population of 284 professionally qualified engineers from a South African company participated in the study. The sample consisted of $70 \%$ white employees, $60 \%$ men and 50\% employees under the age of 36 years. The participants had been employed by the company for a minimum of three years and were in the early stages of their careers.

\section{Measures}

The Organisational Commitment Questionnaire (OCQ) (Meyer \& Allen, 1991) was used to measure employees' level of commitment to their organisation. The OCQ consists of 24 items measured on a seven-point Likert scale, ranging from 1 (strongly disagree) to 7 (strongly agree). Examples 
of items in each of the three OCQ dimensions include the following: affective ('I would be very happy to spend the rest of my career in this organisation'), continuance ('One of the major reasons I continue to work for this organisation is that leaving would require considerable personal sacrifice; another organisation may not match the overall benefits I have here'), normative ('I do not feel any obligation to remain with my current employer'). Meyer and Allen (1997) reported the following internal consistency Cronbach's alpha coefficients: 0.85 for affective, 0.79 for continuance and 0.73 for normative commitment. The present study yielded acceptable internal consistency reliability (Cronbach's alpha) coefficients: 0.89 for affective, 0.68 for continuance and 0.88 for normative commitment.

The Organisational Culture Survey (OCS) (Deloitte \& Touche, 2009) was used to measure employees' perceptions regarding 13 organisational HR practices. These practices are seen to affect a company's performance and are therefore deemed to be important for creating a strong performanceoriented organisational culture. The OCS consists of 80 items measured on a seven-point Likert scale ranging from 1 (strongly disagree) to 7 (strongly agree). Examples of items in each Human Resource Management (HRM) practice dimension include the following: change management ('In this organisation, employees are encouraged to become involved in and committed to change'), communication ('Communication messages are effective and understood by allemployees'), diversity and transformation('Understanding and respecting diversity is important in this organisation'), HR policies and procedures ('A concerted effort is made to educate employees on the HR policies and procedures in place'), innovation ('Innovation has been communicated to employees as being a strategic business objective in the organisation'), job satisfaction ('In general, employees find their work interesting and challenging'), leadership ('Most employees are inspired and motivated by leadership in this organisation'), management style ('The person I report to involves employees in decisions that affect their job and work performance'), performance management ('Employee performance is managed against clear and measurable objectives'), recognition ('This organisation recognises employees who behave according to the organisation's values'), rewards and remuneration ('Employees' total remuneration packages - salary plus bonus and incentives - are market-related'), training and development ('Training and development for future career advancement is available to all employees') and values and culture ('There is a culture of honesty, openness and trust in the organisation'). The OCS is a well-established instrument that is widely used by Deloitte and Touche (2009), with proven validity and reliability in the South African business environment. The present study yielded high internal consistency reliability (Cronbach's alpha coefficients) for the various dimensions of the BCPS: 0.88 for change management, 0.84 for communication, 0.80 for diversity and transformation, 0.84 for HR policies and procedures, 0.79 for innovation, 0.88 for job satisfaction, 0.91 for leadership, 0.91 for management style, 0.98 for performance management, 0.88 for recognition, 0.86 for rewards, 0.88 for training and development and 0.83 for values and culture.

\section{Research procedure}

In terms of ethical considerations, permission to conduct the research was obtained from the management of the engineering organisation. The research institution granted ethical clearance. Participants completed an informed consent form and it was indicated to them that the completion and return of the questionnaires and consent forms signified that they had granted permission for their responses to the questionnaires to be used for research purposes. Participation was voluntary and the confidentiality of the participants was maintained.

\section{Data analysis}

The first stage involved determining the means, standard deviations and Cronbach's alpha coefficients. In the second stage, Pearson product moment correlations were calculated in order to specify the relationship between the HR practices measured by the OCS and the OCQ variables. In terms of statistical significance, it was decided to set a cut-off alpha value at the $95 \%$ confidence interval level $(p \leq 0.05)$. In the last stage, stepwise regression analysis was performed to determine whether or not the HR practices measured by the OCS act as significant predictors of the OCQ variables. For the purpose of this study, $R^{2}$ values larger than 0.50 (large effect) at $p \leq 0.05$ (Cohen, 1992) were regarded as practically significant:

Prior to conducting the various regression analyses, collinearity diagnostics were examined to ensure that zero-order correlations were below the level of concern $(r \geq 0.80)$, that the variance inflation factors did not exceed 10, that the condition index was well below 15 and that the tolerance values were close to 1.0 (Field, 2009). (Harry \& Coetzee 2013, n.p.)

\section{Results \\ Descriptive statistics and correlations}

The descriptive statistics and internal consistency reliability coefficients of the measuring instruments are reported in Table 1.

The significant correlation coefficients between the HR practices and the three organisational commitment variables $(p \leq 0.05)$ are reported in Table 1. As can be observed from Table 1, the correlations between affective and normative commitment and the HR practices mostly ranged between 0.40 (medium practical effect size) and 0.70 (large practical effect size). The correlations between continuance commitment and the HR practices ranged between 0.10 and 0.21 (small practical effect size). No significant correlation was observed between continuance commitment and training and development. These results showed that the zero-order correlations were well below the threshold level of concern $(r \geq 0.80)$ about multicollinearity and warranted further analysis in the form of regression analysis. 


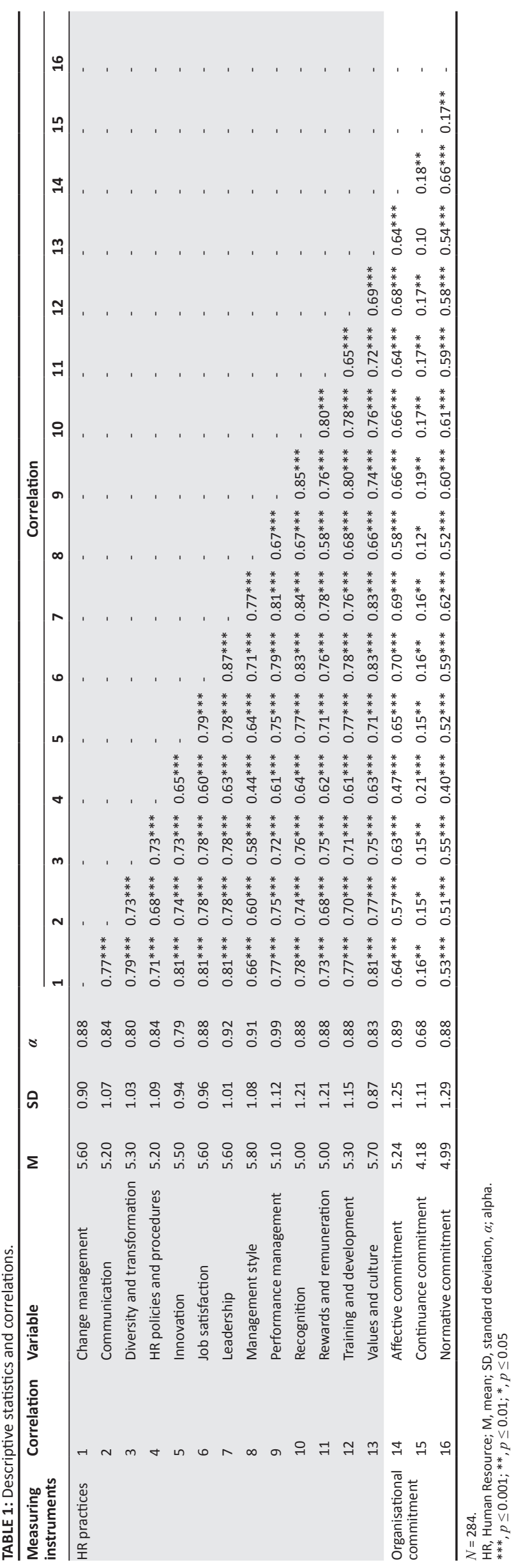

\section{Stepwise multiple regressions}

Three separate stepwise regression models were calculated, one model for each of the three OCQ dependent variables: affective commitment, continuance commitment and normative commitment. Each of the three stepwise regression models shows the HR practices that significantly explained the variance in each of the three commitment variables respectively.

In model 1, Table 2 indicates that the regression of the HR practices upon the affective commitment variable produced a statistically significant model $(F=85.21 ; p \leq$ $0.001)$, accounting for approximately $55 \%\left(R^{2}=0.55\right.$; large practical effect) of the variance in affective commitment. More specifically, job satisfaction $(\beta=0.33 ; \mathrm{t}=4.36 ; p \leq 0.000)$, training and development $(\beta=0.28 ; t=4.22 ; p \leq 0.000)$ and rewards $(\beta=0.20 ; t=3.24 ; p \leq 0.001)$ contributed significantly towards explaining the proportion of variance in the affective commitment variable.

In model 2, Table 2 indicates that the regression of the HR practices upon the continuance commitment variable produced a statistically significant model $(F=13.29 ; p \leq$ $0.001)$, accounting for approximately $5 \%\left(R^{2}=0.05\right.$; small practical effect) of the variance in continuance commitment. Only HR policies and procedures $(\beta=0.21 ; \mathrm{t}=2.95 ; p \leq 0.001)$ contributed significantly and positively in explaining the variance in continuance commitment.

In model 3, Table 2 indicates that the regression of the HR practices upon the normative commitment variable produced a statistically significant model $(F=71.09 ; p \leq 0.001)$, accounting for $43 \%\left(R^{2}=0.44\right.$; large practical effect $)$ of variance in normative commitment. More specifically, leadership $(\beta=$ $0.28 ; \mathrm{t}=3.32 ; p \leq 0.001)$, rewards and remuneration $(\beta=0.24 ; t=$ 3.27; $p \leq 0.001)$ and training and development $(\beta=0.21 ; t=2.95$; $p \leq 0.001)$ contributed significantly towards explaining the proportion of variance in the normative commitment variable.

A test of the difference of dependent multiple R's, after conversion to $z$-scores, revealed a significant difference between the affective commitment multiple $\mathrm{R}$ and the normative commitment multiple $\mathrm{R}(z=1.96 ; p \leq 0.05)$. Similarly to the correlation results reported in Table 1 , these results imply that the identified set of significant HR practices (training and development and rewards and remuneration) are, in general, more strongly related to affective commitment than to normative commitment. However, an analysis of the profiles of beta values of these three HR practices showed that they differed significantly in the two regression analyses reported in Table 2 for affective commitment and normative commitment. Rewards and remuneration explained significantly more variance in normative commitment than in affective commitment, whilst training and development explained significantly more variance in affective commitment than in normative commitment. 
TABLE 2: Stepwise regression results - significant human resource practices as predictors of affective, continuance and normative commitment.

\begin{tabular}{llll}
\hline Variable & Model 1: Affective commitment & Model 2: Continuance commitment & Model 3: Normative commitment \\
\hline Job satisfaction & $0.33^{* * *}$ & - & - \\
Training and development & $0.28^{* * *}$ & - & $0.21^{* *}$ \\
Rewards and remuneration & $0.20^{* *}$ & - & $0.24^{* * *}$ \\
Human Resource policies and procedures & - & $0.21^{* * *}$ & - \\
Leadership & - & - & $0.28^{* * *}$ \\
F-statistic & $85.21^{* * *}$ & $13.29^{* * *}$ & $71.09^{* * *}$ \\
$R^{2}$ & 0.55 & 0.05 & 0.44 \\
adjusted $R^{2}$ & 0.55 & 0.04 & 0.43 \\
\hline
\end{tabular}

Standardised beta weights are reported for the final step in each model.

$N=284$

${ }^{* * *}, p \leq 0.001 ; * *, p \leq 0.01$

\section{Discussion}

The purpose of this study was to examine whether HR practices (as a core aspect of organisational culture) significantly predicted employees' organisational commitment. Overall, the correlations showed positive associations between the variables. More specifically, the results showed that the participants' perceptions of HR practices acted as positive predictors of their level of commitment towards the organisation. More specifically, job satisfaction, training and development and rewards and remuneration significantly and positively predicted the participants' affective commitment. Leadership, rewards and remuneration and training and development further positively predicted the participants' normative commitment, whilst HR policies and procedures significantly and positively predicted the participants' continuance commitment. The positive relationship observed between these HR practices and affective, continuance and normative commitment appears to corroborate previous research about these HR practices as being retention factors that increase employees' commitment to the organisation (Döckel, 2003; Döckel et al., 2006; Van Dyk \& Coetzee, 2012).

Affective commitment reflects a mindset of desire that develops when employees see their individual employment relationship as being in harmony with the goals and values of the organisation for which they are currently working (Ferreira, Basson \& Coetzee, 2010). When employees become involved in and recognise the value and relevance of their association with the organisation in the pursuit of their jobs and careers, they develop a mindset of desire to stay (Meyer \& Herscovitch, 2001). In the present study, training and development and job satisfaction were indicated as the two strongest predictors of the participants' affective commitment. It appears from the results that providing training and development opportunities and enhancing employees' job satisfaction by setting clear work objectives, providing them with necessary tools and resources to perform their jobs effectively and affording them the opportunity to fully utilise their talents and skills (Deloitte \& Touche, 2009) will significantly increase their emotional attachment to the organisation. Döckel et al. (2006) found that employees are more likely to be emotionally bound to an organisation that provides proper training and career opportunities. Ghazanfar, Chuanmin, Bashir and Yang (2012) also found that the training and development of employees are important in enhancing their commitment to the organisation. Employees' job satisfaction has also been positively related to affective and normative commitment (Lumley, Coetzee, Tladinyane \& Ferreira, 2011; Shah et al., 2012).

The results of the present study further showed that rewards and remuneration (market-related remuneration, benefits and non-monetary recognition incentives) are important in enhancing the participating employees' affective commitment. Lumley et al. (2011) also found pay satisfaction as an important antecedent of affective commitment. Meyer and Allen (1997) posit that an organisation that offers attractive compensation packages to employees shows their employees that they do matter to the organisation, which consequently enhances their emotional bond with the organisation.

Continuance commitment refers to commitment based on the cost that the employee associates with leaving the organisation (Meyer \& Allen, 1997). The observed relationships between HR policies and procedures and continuance commitment are in line with research conducted by Meyer and Allen (1997). These authors found HR policies and procedures to be effective strategies for managing organisational commitment.

Normative commitment reflects a mindset of obligation, which develops as a result of the internalisation of norms through socialisation and the receipt of benefits (which encourages a feeling that one should reciprocate), or acceptance of the terms of a psychological contract (Ferreira et al., 2010). The results of the present study showed that this mindset is cultivated by positive perceptions of leadership, rewards and remuneration and training and development opportunities. Leadership has been related to positive organisational behaviour, which fosters engaged employees, higher performance and commitment, which, in turn, lowers the risk of losing talent (Kiyani et al., 2011; Mendes \& Stander, 2011). Döckel et al. (2006) and Lumley et al. (2011) found pay to have a direct effect on normative commitment. According to Meyer and Allen (1997), high performancebased pay creates an economic obligation for an individual to remain with an organisation. Brundage and Koziel (2010) also confirm the importance of establishing a compensation system that focuses not only on salary and benefits but also on career development and growth opportunities in order to retain talented staff. 


\section{Managerial implications}

Overall, the findings of the study add to the retention literature by shedding new light on how employees' perceptions of HR practices in the South African engineering environment relate to their levels of organisational commitment. The results seem to corroborate research conducted by Martin and Roodt (2008), which indicates that employees value certain conditions of work and if these conditions are evident and congruent with the individual's own needs, employees will be more satisfied and committed and less likely to leave the organisation (Lumley et al., 2011). In practical terms, the new knowledge gained from the observed relationship between the HR practices of leadership, training and development, rewards and remuneration and job satisfaction and the participants' affective and normative commitment, and HR policies and procedures and continuance commitment, may be useful in the attraction and retention of talented employees in the engineering environment.

Organisations can train their managers to practise leadership behaviours that model the values of the organisation and inspire and motivate employees to deliver better performance and higher levels of commitment (Chang et al., 2013; Detert \& Treviño, 2010). Training and development remain key practices for enhancing affective and normative commitment and, by implication, for retaining valuable staff. Formal and informal training and development opportunities should equip employees with the skills and knowledge they need for future career advancement. Although managers should be held accountable for the development of their employees, employees should be encouraged and empowered to take control of their own growth and development within the organisation by means of regular performance and development discussions (Chang et al., 2013; Döckel et al., 2006).

Fair reward and remuneration practices must be established in order to enhance employees' affective and normative commitment. Remuneration packages should match job roles and responsibilities, be linked to performance and be perceived to be market-related (Brundage \& Koziel, 2010; Chang et al., 2013; Döckel, 2003; Zaitouni et al., 2011). Employees' job satisfaction can be enhanced by ensuring that they are well trained in terms of the knowledge and skills they need to perform their jobs well. Interesting and challenging work that taps into the talents and abilities of employees also assists in enhancing job satisfaction and affective commitment (Döckel, 2003; Van Dyk \& Coetzee, 2012).

In order to enhance employees' continuance commitment, a concerted effort should be made to educate employees on the company's HR policies and procedures. Information about HR policies and procedures should be readily available to everyone. HR policies and procedures should be applied consistently throughout the organisation in order to ensure perceptions of fairness (Döckel, 2003; Paré \& Tremblay, 2007).

\section{Limitations and suggestions for future research}

A number of limitations should be observed with regard to the present study. Given the cross-sectional nature of the research design, this study can yield no statements about causation. The observed associations between the variables have therefore been interpreted rather than established (Lumley et al., 2011). This study was further limited to early career participants with a minimum of three years tenure in a single engineering organisation in South Africa, which means that the results cannot be generalised to other occupational contexts and regions. Future research efforts should be focused on obtaining larger and more representative samples from a more diverse group with longer years of tenure in various occupational sectors. This study may potentially serve as a foundation for researchers to examine, both theoretically and empirically, HR practices and other retention and commitment variables in order to gain further insight into the effect of HR practices as a core aspect of organisational culture on organisational commitment. The results of such studies could be of benefit to organisations when addressing the issue of the retention of engineers and scarce critical skills in other occupations.

\section{Conclusion}

The study contributes to knowledge of HR practices that may potentially influence the attraction and retention of early career engineering staff. The findings underscore the importance of assessing employees' perceptions of HR practices relating to job satisfaction, leadership, training and development, rewards and remuneration and HR policies and procedures as these have been shown to significantly predict higher levels of organisational commitment. The practical implications for managers and HR practitioners are to take a proactive approach in facilitating an organisational culture that reflects the practices embodied by the variables measured in this study.

\section{Acknowledgements Competing interests}

The authors declare that they have no financial or personal relationship(s) that may have inappropriately influenced them in writing this article.

\section{Authors' contributions}

M.C. (University of South Africa) was the project leader and assisted with writing up the article. J.M.-M. (University of South Africa) was responsible for the literature review and assisted with writing up the article. B.S. (University of South Africa) was responsible for the data collection.

\section{References}

Abu-Jarad, I.Y., Yusof, N.A., \& Nikbin, D. (2010). A review paper on organisational culture and organisational performance. International Journal of Business \& Social Sciences, 1, 26-46.

Aggarwal, U., \& D'Souza, K.C. (2012). Transformational leadership: The link between $\mathrm{P}-\mathrm{O}$ fit, psychological contract and signature experiences. The Indian Journal of Labour Relations, 47, 485-497.

Amah, E. (2012). Corporate and organisational effectiveness: A study of the Nigerian banking industry. European Journal of Business \& Management, 4(8), 212-229.

Arachchige, B.J.H., \& Robertson, A. (2011). Business student perceptions of a preferred employer: A study identifying determinants of employer branding. The IUP Journal of Branding Management, VIII, 25-46. 
Bang, H., Ross, S., \& Reio, T.G. (2013). From motivation to organisational commitment of volunteers in non-profit sport organisations: The role of job satisfaction. Journal of Management \& Development, 32, 96-112. http://dx.doi. satisfaction. Journal of Management
org/10.1108/02621711311287044

Brundage, H., \& Koziel, M. (2010). Retaining top talent. Journal of Accountancy, May, 38-44.

Construction Education and Training Authority (CETA). (2007). Construction Education and Training Authority. Pretoria, South Africa: CETA.

Chang, W., Wang, Y., \& Huang, T. (2013). Work design-related antecedents of turnover intention: A multilevel approach. Human Resource Management, 52(1), 1-26. http://dx.doi.org/10.1002/hrm.21515

Coetzee, M., \& Veldsman, D. (2013). Exploring espoused organisational values in relation to lived values experiences in the South African financial sector. African relation to lived values experiences in the Sou
Journal Business Management, 7, 480-489.

Cohen, J. (1992). Quantitative methods in psychology: A power primer. Psychological Bulletin, 112(1), 153-159. http://dx.doi.org/10.1037/0033-2909.112.1.155

Decremer, A., Smolders, C., Vanderstraeten, A., \& Christiaens, J. (2012). The impact of institutional pressures on employee performance management systems in highe education in the low countries. British Journal of Management, 23, 88-103. $\mathrm{http}: / / \mathrm{dx}$.doi.org/10.1111/j.1467-8551.2012.00820.x

Deloitte \& Touche. (2009). Organizational Culture Survey. Pretoria, South Africa: Deloitte \& Touche.

Detert, J.R., \& Treviño, L.K. (2010). Speaking up to higher ups: How supervisor and skip-level leaders influence employee voice. Organisational Sciences, 21, 249270. http://dx.doi.org/10.1287/orsc.1080.0405

Dey, T. (2012). Predictors of organisational commitment and union commitment a conceptual study. Journal of Organizational Behavior, 10, 62-75.

Department of Higher Education and Training (DHET). (2014). Government Gazette Notice 380: National Scarce Skills List, Version 20 May 2014. Pretoria, South Africa: Government Printer.

Döckel, A. (2003). The effect of retention factors on organisational commitment: An investigation of high technology employees. Unpublished master's thesis, University of Pretoria, Pretoria, South Africa.

Döckel, A., Basson, J.S., \& Coetzee, M. (2006). The effect of retention factors on organisational commitment: An investigation of high technology employees. South African Journal of Human Resource Management, 42, 20-28.

Eskildsen, J.K., \& Dahlgaard, J.J. (2000). A causal model for employee satisfaction. Total Quality Management, 11(8), 1081-1094. http://dx.doi. org/10.1080/095441200440340

Ezirim, C.B., Nwibere, B.M., \& Emecheta, B.C. (2012). The influence of corporate culture on organisational commitment: The Nigerian experience. Internationa Journal Business \& Public Administration, 9, 155-180.

Ferreira, N., Basson, J.S., \& Coetzee, M. (2010). Psychological career resources in relation to organisational commitment: An exploratory study. South African Journal of Human Resource Management, 8(1), Art. \#284, 10 pages. http://dx.doi. org/10.4102/sajhrm.v8i1

Field, A. (2009). Discovering statistics using SPSS. (3rd edn.). Thousand Oaks, CA: Sage.

Ghazanfar, F., Chuanmin, S., Bashir, M., \& Yang, L. (2012). Human resource management practices and organisational commitment: Empirical evidence 11(100), 1397-1406.

Ghina, A. (2012). The influence of corporate culture on organisational commitment: Case study of civil government organisations in Indonesia. International Journal of Basic \& Applied Sciences, 1(2), 156-170.

Harry, N., \& Coetzee, M. (2013). Sense of coherence, career adaptability and burnout of early-career Black staff in the call centre environment. SA Journal of Industrial Psychology/SA Tydskrif vir Bedryfsielkunde, 39(2), Art. \#1138, 10 pages. http:// dx.doi.org/10.4102/sajip.v39i2.1138

Jonsen, K., Tatli, A., Ozbilgin, M.F., \& Bell, M.P. (2013). The tragedy of the uncommon: Reframing workforce diversity. Human Relations, 66(2), 271-294. http://dx.doi. org/10.1177/0018726712466575

Juhdi, N., Pa'Wan, F., Milah, R., Hansaram, S.K., \& Othman, N.A. (2012). HR practices, organisational commitment and turnover intention: A study on employees in organisational commitment and turnover intention: A study on emp
Klang Valley, Malaysia. Recent Research in Applied Economy, 9, 30-36.

Khandelwal, K.A., \& Mohendra, N. (2010). Espoused organizational values, vision, and corporate social responsibility: Does it matter to organizational members?
Vikalpa, 35(3), 10-35.

Kiyani, A., Haroon, M., Liaqat, A.S., Khattak, M.A., Bukhari, S.J.A., \& Asad, R. (2011). Emotional intelligence and employee participation in decision-making. African Journal of Business Management, 5(12), 4775-4781.

Kraak, A. (2008). The education-economy relationship in South Africa, 2001-2005, Human Resources Development Review. Cape Town, South Africa: HSRC.

Kuo, Y.K. (2013). Organisational commitment in an intense competition environment. Industrial Management \& Data System, 113(1), 39-59. http://dx.doi. Industrial Management \& Data
org/10.1108/02635571311289656

Lin, S.C., Lin, J.S.J., \& Lin, Y.F. (2012). Human resource management practices affecting organisational commitment: A study on CEO's transformational leadership. African Journal of Business Management, 6(22), 6575-6586.

Lumley, E.J., Coetzee, M., Tladinyane, R.T., \& Ferreira, N. (2011). Exploring the job satisfaction and organisational commitment of employees in the information technology environment. Southern African Business Review, 15(10), 100-118.

Martins, N., \& Coetzee, M. (2007). Organisational culture, employee satisfaction, perceived leader emotional competency and personality type: An exploratory study of a South African engineering company. South African Journal for Human Resource Management, 5(2), 20-32.
Martins, E., \& Martins, N. (2002). An organizational culture model to promote creativity and innovation. South African Journal of Industrial Psychology, 28(4), $54-65$.

Martin, A., \& Roodt, G. (2008). Perceptions of organisational commitment, job satisfaction and turnover intentions in a post-merger South African tertiary institution. South African Journal of Industrial Psychology, 34(1), 23-31.

Mendes, F., \& Stander, M. (2011). Positive organisation: The role of leader behaviour in work engagement and retention. South African Journal of Industrial Psychology, $37(1), 29-41$.

Meyer, J., \& Allen, N. (1991). A three component conceptualisation of organisational commitment. Human Resource \& Management Review, 1, 61-89. http://dx.doi. commitment. Human Resource \& M
org $10.1016 / 1053-4822(91) 90011-Z$

Meyer, J.P., \& Allen, N.J. (1997). Commitment in the workplace: Theory, research and application. Thousand Oaks, CA: Sage.

Meyer, J., \& Herscovitch, L. (2001). Commitment in the workplace toward a general model. Human Resource \& Management Review, 11, 299-326. http://dx.doi. org/10.1016/S1053-4822(00)00053-X

Meyer, J.P., Stanley, L.J., \& Parfyonova, N.M. (2012). Employee commitment in context: The nature and implication of commitment profiles. Journal of Vocational Behavior, 80(1), 1-16. http://dx.doi.org/10.1016/j.jvb.2011.07.002

Momeni, M., Marjani, A.B., \& Saadat, V. (2012). The relationship between organisational culture and organisational commitment in staff development of general prosecutors of Tehran. International Journal of Business \& Social Sciences, 3(13), 217-221.

Pandey, S., \& De, D. (2013). Role of innovation in practices human resources for organisational competitiveness: An empirical investigation. Driving Economy Through Innovation \& Entrepreneurship, 29, 355-365. http://dx.doi. org/10.1007/978-81-322-0746-7_29

Papulova, E., \& Papulova, Z. (2006). Competitive strategy and competitive advantages of small and midsized manaufacturing enterprises in Slovakia. Slovakia: e-Leader.

Paré, G., \& Tremblay, M. (2007). The influence of high-involvement human resources practices, procedural justice, organisational commitment, and citizenship behaviours on information technology professionals' turnover intentions. Group Organisation \& Management, 32(3), 326-357. http://dx.doi. intentions. Group Organisation \&
org/10.1177/1059601106286875

Rashid, Z.A., Sambasivan, M., \& Johari, J. (2002). The influence of corporate culture and organisational commitment on performance. Journal of Management \& Development, 22(8), 708-728. http://dx.doi.org/10.1108/02621710310487873

Rasool, F., \& Botha, C.J. (2011). The nature, extent and effect of skills shortages on skills migration in South Africa. South African Journal of Human Resource Management, $9(1), 1-12$

Reade, C., \& Lee, H.J. (2012). Organisational commitment in time of war: Assessing the impact and attenuation of employee sensitivity to ethno-political conflict. Journa of International Management, 18(1), 85-101. http://dx.doi.org/10.1016/j. intman.2011.09.002

Rostami, R., Veismoradi, A., \& Akbari, P. (2012). The relationship between organisational climate, organisational commitment and innovation in Cement West Company of Kermanshah. Technical Journal of Engineering, 2, 12-19.

Rothrauff, T.C., Abraham, A.J., Bride, B.E., \& Roman, P.M. (2011). Occupational turnover intentions among substance abuse counsellors. Journal of Substance Abuse Treatment, 40, 67-76. http://dx.doi.org/10.1016/j.jsat.2010.08.008

Saif, S.K., Nawaz, A., Jan, F.A., \& Khan, M.I. (2012). Synthesizing the theories of job satisfaction across the cultural/attitudinal dementions. International Journal of Contingency Research \& Business, 3(9), 1382-1396.

Shah, S.M.A., Jatoi, M.M., \& Memon, M.S. (2012). The impact of organisational culture on the employees' job satisfaction and organisational commitment: A study of faculty members of private sector universities of Pakistan. International study of faculty members of private sector universities of
Journal Contingency Research \& Business, 3(11), 809-829.

Swart, B. (2009). Best company practices and organisation commitment: An exploratory study of an engineering company. Unpublished MBA dissertation, Graduate School of Business Leadership, University of South Africa, Pretoria, South Africa.

Tsai, M.T., \& Cheng, N.C. (2011). Understanding knowledge sharing between it professionals - An integration of social cognitive and social exchange theory. Behaviour Information \& Technology, 31(11), 1-12.

Van Dyk, J., \& Coetzee, M. (2012). Retention factors in relation to organisational commitment in medical and information technology services. South African Journal of Human Resource \& Management, 10(2), 433-444.

Visagie, C.M., \& Steyn, C. (2011). Organisational commitment a responses to planned organisational change: An exploratory study. Southern African Business Review, 15(3), 98-129.

Wöcke, A., \& Heymann, M. (2012). Impact of demographic variables on voluntary labour turnover in South Africa. International Journal of Human Resource Management, 23(16), 3479-3494. http://dx.doi.org/10.1080/09585192.2011.6 39028

Zaitouni, M., Sawalha, N.N., \& Sharif, A. (2011). The impact of human resource management practices on organisational commitment in the banking sector in Kuwait. International Journal Business \& Management, 6(6), 108-123. http:// dx.doi.org/10.5539/ijbm.v6n6p108

Zeffane, R. (1994). Patterns of organisational commitment and perceived management style: A comparison of public and private sector employees. Human Relations, 47(8), 977-1003. http://dx.doi.org/10.1177/001872679404700806 